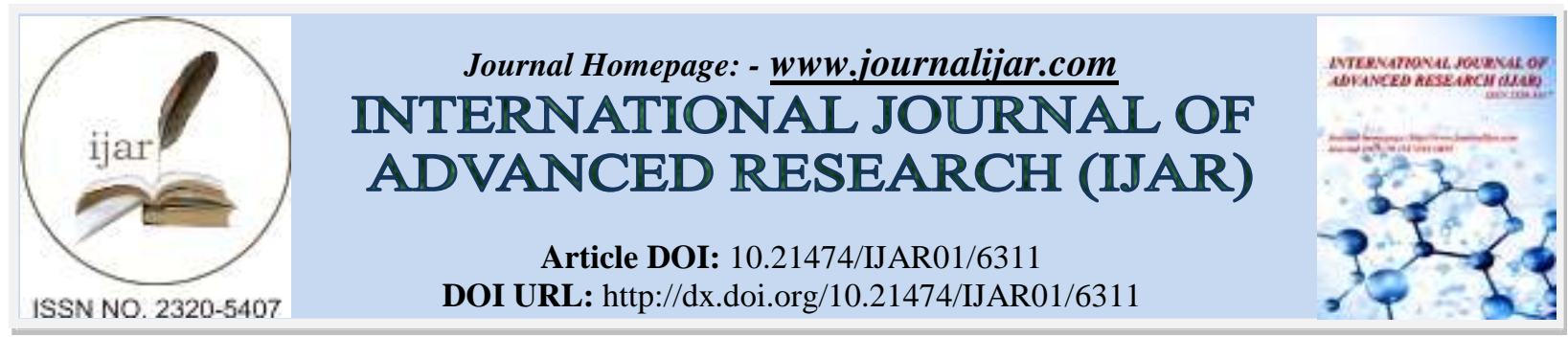

RESEARCH ARTICLE

\title{
EFFECT OF HEAVY METAL CONCENTRATIONS ON SOME FISHES IN KAFR EL-ZAYAT AREA, ROSETTA BRANCH, RIVER NILE, EGYPT.
}

Wafai Z. A. Mikhail ${ }^{1}$, Heba I. A. El-Safty ${ }^{1}$ and Mohammed G. A. Gad ${ }^{2}$.

1. Dept. Natural Resources, Inst. African Research \& Studies, Cairo University.

2. Inst. Environmental Studies and Research, Sadat University.

\section{Manuscript Info}

Manuscript History

Received: 15 November 2017

Final Accepted: 17 December 2017

Published: January 2018

Key words:-

Heavy metals, catfish, Rosetta Branch, Oreochromis niloticus.

\begin{abstract}
Five sites in the water of Rosetta Branch were selected to investigate heavy metal concentrations. In this study there are great variations in the studied parameters according to the distance from the source of pollution. Heavy metal concentrations are strongly affected by the industrial effluents produced from each of El-Mobidat, El-Malyia and Salt and Soda companies which directly discharge industrial effluents at this area without any treatments. Correlation coefficient and regression analysis were also studied.
\end{abstract}

Copy Right, IJAR, 2018,. All rights reserved.

\section{Introduction:-}

In Egypt, the effect of heavy metals on fish is of great importance since fish is becoming a necessity as relatively cheap source of animal protein and may compensate for the present deficiency of other expensive protein (Zaghloul et al., 2001). Heavy metals exert a wide range of effects on fish, from metabolic and physiological to behavioral and ecological aspects (El-Naggar et al., 1998).

The level of metals bioaccumulation in fish tissues is influenced by abiotic and biotic factor, such as fish biological habitat, chemical form of metals in the water, water temperature, $\mathrm{pH}$ value, dissolved oxygen, water transparency as well as by fish age, gender, body mass and physiological conditions (Has-Schon $\boldsymbol{e t}$ al., 2006). In addition, there are significant differences in the concentrations of elements across fish species related to organisms mobility, food preference or behavior with respect to environment (Demirezen and Uruc, 2006).

The aim of the present study is to study the effect of different pollutants such as industrial and sewages on water quality of River Nile in Egypt and some species of Nile fishes; the Nile tilapia or bulti, bayad or silver catfish and the African catfish or catfish, which were collected from different Nile sites in Kafr El Zayat area.

\section{Materials:-}

\section{Study sites:-}

This study was conducted at Kafr El- Zayat town. It located on Rosetta branch of the River Nile. Five sites in the study area were selecte:

1. Tala drainage: drain sewage water directly in Nile water.

2. The second site is located by about $200 \mathrm{~m}$ away from the first site.

3. This site is in-between sites 2 and 3 in middle of Rosetta branch water. 
4. The area of industrial companies which drain their waste water into Nile water. These companies change it drain outlet from this area into Ganag drain which drains directly into Borolos Lake in the north.

5. This site after site 4 by about $150-200 \mathrm{~m}$.

\section{Water samples:-}

were taken with a water sampler from each site seasonally. Duplicates of water samples were taken from each of the five studied sites, between 10:00 and 12:00 a.m. at a depth of $30 \mathrm{~cm}$ below the water surface and stored at $4^{\circ} \mathrm{c}$ in clean1000 ml sampling glass bottles according to Boyd (1990).

\section{Fish species:-}

The present comparative study was carried out on three different species of fish in the River Nile in Egypt; the Nile tilapia or bulti, Oreochromis niloticus (Perciformes; Cichlidae); bayad or silver catfish Bagrus bayad (Siluriformes; Bagridae); and the African catfish or catfish Clarias gariepinus (Siluriformes; Clariidae). The three fish species were collected seasonally during (2015-2016) from the studied sites. The fishes were immediately dissected to extract muscle samples.

\section{Methods:-}

Water heavy metals concentration ( $\mathrm{Fe}, \mathrm{Mn}, \mathrm{Cu}, \mathrm{Cd}, \mathrm{Ni})$ were determined by a Perkin-Elmer 2380 atomic absorption spectrophotometer (AAS) according to APHA(2005).

The collected fishes were washed with de-ionized water, put in cleaned plastic bags and stored frozen until analysis was carried out. One gram of muscle tissue sample (wet weight) was subjected to digestion by adding $10 \mathrm{ml}$ of freshly prepared $1: 1$ concentrated $\mathrm{HNO}_{3}-\mathrm{HClO}_{3}$ in beaker, covered with a watch glass till initial reaction subsided in about 1 hour and gently heated at $160^{\circ} \mathrm{C}$ in a sand bath on a hot plate till reduction of volume to $2-5 \mathrm{ml}$. The digested samples were allowed to cool and transferred into $25 \mathrm{ml}$ volumetric flasks and made up to mark with de-ionized water (Olaifa et al., 2004). Heavy metal concentrations ( $\mathrm{Fe}, \mathrm{Mn}, \mathrm{Cu}, \mathrm{Cd}, \mathrm{Ni}$ ) were determined using flame atomic absorption spectrophotometer (Thermo Scientific ICE 3300, UK) with double beam and deuterium background corrector according to (APHA, 2005).

\section{Results:-}

The concentration of heavy metals $(\mathrm{Fe}, \mathrm{Mn}, \mathrm{Cu}, \mathrm{Cd}$ and $\mathrm{Ni}$ ) in water samples expressed in unit of $\mathrm{mg} / \mathrm{l}$ were show in Table ( 1$)$. The concentrations of the heavy metals tested in this study were significantly different $(p \leq 0.05)$ in either sites or seasons of the present study, except for that of Fe, which show no significant differences in sites as well as seasons. However, generally speaking, the concentrations of iron in each of sites and seasons were higher than that of the other heavy metals tested.

Regarding the concentration of these heavy metals recorded in the different seasons, it is noticed that; the concentration of each of $\mathrm{Fe}, \mathrm{Cu}$, and $\mathrm{Cd}$ were higher in spring season. For the concentrations of each of $\mathrm{Mn}$ and $\mathrm{Ni}$, were higher in summer and autumn seasons, respectively. Lower values of each of $\mathrm{Fe}$ and $\mathrm{Cd}$ were recorded in summer season, and for $\mathrm{Cu}$ and $\mathrm{Ni}$ in winter season, whereas $\mathrm{Mn}$ in autumn season. Site 1 has higher concentrations of each of $\mathrm{Fe}, \mathrm{Cu}$, and $\mathrm{Ni}$; while site 5 has high values of each of $\mathrm{Mn}$ and $\mathrm{Cd}$. On the other hand, site 2 has low values of $\mathrm{Fe}$ and $\mathrm{Mn}$ and site 5 has low values of $\mathrm{Cd}$ and $\mathrm{Ni}$ whereas, site 3 has low value of $\mathrm{Cu}$.

Table 1:- Seasonal variation of heavy metal concentrations in water samples in different sites.

\begin{tabular}{|c|c|c|c|c|c|}
\hline Metal & Site & Summer2015 & Autumn & Winter2016 & Spring \\
\hline \multirow{4}{*}{ Fe } & $\mathbf{1}$ & $2.331^{\mathrm{a}}$ & $5.000^{\mathrm{a}}$ & $4.953^{\mathrm{a}}$ & $5.463^{\mathrm{a}}$ \\
\cline { 2 - 6 } & $\mathbf{2}$ & $1.040^{\mathrm{a}}$ & $4.140^{\mathrm{a}}$ & $4.077^{\mathrm{a}}$ & $5.030^{\mathrm{a}}$ \\
\cline { 2 - 6 } & $\mathbf{3}$ & $3.416^{\mathrm{a}}$ & $4.750^{\mathrm{a}}$ & $3.647^{\mathrm{a}}$ & $4.637^{\mathrm{a}}$ \\
\cline { 2 - 6 } & $\mathbf{4}$ & $2.334^{\mathrm{a}}$ & $5.010^{\mathrm{a}}$ & $4.332^{\mathrm{a}}$ & $5.003^{\mathrm{a}}$ \\
\cline { 2 - 6 } & $\mathbf{5}$ & $1.111^{\mathrm{a}}$ & $4.620^{\mathrm{a}}$ & $3.667^{\mathrm{a}}$ & $4.253^{\mathrm{a}}$ \\
\hline \multirow{4}{*}{ Mn } & $\mathbf{1}$ & $1.341^{\mathrm{a}}$ & $0.170^{\mathrm{c}}$ & $0.994^{\mathrm{bc}}$ & $0.028^{\mathrm{bc}}$ \\
\cline { 2 - 6 } & $\mathbf{2}$ & $0.943^{\mathrm{bcd}}$ & $\mathbf{0 . 1 2 0}^{\mathrm{g}}$ & $0.471^{\mathrm{ef}}$ & $0.504^{\mathrm{e}}$ \\
\cline { 2 - 6 } & $\mathbf{3}$ & $0.874^{\mathrm{cd}}$ & $0.160^{\mathrm{g}}$ & $0.166^{\mathrm{g}}$ & $0.701^{\mathrm{de}}$ \\
\cline { 2 - 6 } & $\mathbf{4}$ & $1.200^{\mathrm{ab}}$ & $0.140^{\mathrm{g}}$ & $0.242^{\mathrm{gg}}$ & $0.139^{\mathrm{g}}$ \\
\cline { 2 - 6 } & $\mathbf{5}$ & $\mathbf{1 . 3 5 6}^{\mathrm{a}}$ & $0.200^{\mathrm{g}}$ & $0.131^{\mathrm{g}}$ & \\
\hline
\end{tabular}




\begin{tabular}{|c|c|c|c|c|c|}
\hline \multirow[t]{5}{*}{$\mathrm{Cu}$} & 1 & $0.141^{\mathrm{g}}$ & $0.210^{\mathrm{de}}$ & $0.279^{b}$ & $0.360^{\mathrm{a}}$ \\
\hline & 2 & $0.134^{\mathrm{g}}$ & $0.220^{\mathrm{d}}$ & $0.146^{\mathrm{c}}$ & $0.149^{\mathrm{g}}$ \\
\hline & 3 & $0.145^{\mathrm{g}}$ & $0.200^{\mathrm{ef}}$ & $0.035^{k}$ & $0.140^{g}$ \\
\hline & 4 & $0.187^{\mathrm{f}}$ & $0.240^{\mathrm{c}}$ & $0.112^{\mathrm{h}}$ & $0.195^{\mathrm{ef}}$ \\
\hline & 5 & $0.200^{\text {ef }}$ & $0.210^{\mathrm{de}}$ & $0.052^{j}$ & $0.078^{i}$ \\
\hline \multirow[t]{5}{*}{ Cd } & 1 & $0.059^{\mathrm{f}}$ & $0.140^{b}$ & $0.133^{b}$ & $0.164^{a}$ \\
\hline & 2 & $0.012^{\mathrm{h}}$ & $0.110^{\mathrm{c}}$ & $0.104^{\mathrm{cd}}$ & $0.144^{\mathrm{b}}$ \\
\hline & 3 & $0.009^{\mathrm{h}}$ & $0.070^{\mathrm{f}}$ & $0.063^{f}$ & $0.058^{f}$ \\
\hline & 4 & $0.036^{\mathrm{g}}$ & $0.100^{\text {cde }}$ & $0.144^{b}$ & $0.110^{\mathrm{c}}$ \\
\hline & 5 & $0.008^{h}$ & $0.090^{\mathrm{de}}$ & $0.087^{\mathrm{e}}$ & $0.066^{\mathrm{f}}$ \\
\hline \multirow[t]{5}{*}{$\mathrm{Ni}$} & 1 & $0.214^{\mathrm{d}}$ & $0.210^{d}$ & $0.270^{\mathrm{a}}$ & $0.224^{\mathrm{cd}}$ \\
\hline & 2 & $0.235^{\mathrm{bc}}$ & $0.170^{\text {gh }}$ & $0.193^{\mathrm{ef}}$ & $0.180^{\mathrm{fg}}$ \\
\hline & 3 & $0.208^{\mathrm{de}}$ & $0.170^{\text {gh }}$ & $0.148^{\mathrm{ijk}}$ & $0.139^{j k}$ \\
\hline & 4 & $0.213^{\mathrm{d}}$ & $0.15^{\mathrm{ijk}}$ & $0.162^{\text {hi }}$ & $0.162^{\text {hi }}$ \\
\hline & 5 & $0.246^{\mathrm{b}}$ & $0.177^{\text {fgh }}$ & $0.134^{k}$ & $0.151^{\mathrm{ij}}$ \\
\hline
\end{tabular}

Means with different superscript letters for each metal are statistically significant at $p \leq 0.05$

The concentration of heavy metals (Fe, $\mathrm{Mn}, \mathrm{Cu}, \mathrm{Cd}$ and $\mathrm{Ni}$ ) in muscles of three species; Oreochromis niloticus (bulti) Bagrus bayad (bayad)and Clarias gariepinus (catfish) are expressed in unit of $\mu \mathrm{g} / \mathrm{g}$ wet wt and were show in Table ( 2 ).

Table 2:- Seasonal variation of heavy metals in muscles of three species of Fish

\begin{tabular}{|c|c|c|c|c|c|}
\hline Metal & Fish & Sum 2015 & Aut 2015 & Win 2016 & Spr 2016 \\
\hline \multirow[t]{3}{*}{$\mathrm{Fe}$} & bulti & $2.146^{\mathrm{h}}$ & $3.000^{\mathrm{e}}$ & $2.872^{\mathrm{g}}$ & $2.907^{\mathrm{f}}$ \\
\hline & bayad & $1.432^{\mathrm{i}}$ & $1.23^{j}$ & $1.177^{\mathrm{k}}$ & $0.893^{1}$ \\
\hline & catfish & $3.752^{\mathrm{a}}$ & $3.365^{\mathrm{d}}$ & $3.670^{\mathrm{b}}$ & $3.420^{\mathrm{c}}$ \\
\hline \multirow[t]{3}{*}{$\mathrm{Mn}$} & bulti & $0.134^{\mathrm{d}}$ & $0.011^{\mathrm{g}}$ & $0.152^{\mathrm{c}}$ & $0.043^{\mathrm{f}}$ \\
\hline & bayad & $0.088^{\mathrm{e}}$ & $0.003^{\mathrm{g}}$ & $0.087^{\mathrm{e}}$ & $0.052^{f}$ \\
\hline & catfish & $0.188^{\mathrm{a}}$ & $0.152^{\mathrm{c}}$ & $0.178^{\mathrm{ab}}$ & $0.163^{b c}$ \\
\hline \multirow[t]{3}{*}{$\mathrm{Cu}$} & bulti & $0.017^{\mathrm{abcd}}$ & $0.012^{\text {bcde }}$ & $0.018^{\mathrm{abc}}$ & $0.014^{\text {bcde }}$ \\
\hline & bayad & $0.004^{\text {cde }}$ & $0.001^{\mathrm{de}}$ & $0.004^{\text {cde }}$ & $0.000^{\mathrm{e}}$ \\
\hline & catfish & $0.032^{\mathrm{a}}$ & $0.022^{\mathrm{ab}}$ & $0.032^{\mathrm{a}}$ & $0.021^{\mathrm{ab}}$ \\
\hline \multirow[t]{3}{*}{$\mathrm{Cd}$} & bulti & $0.017^{\mathrm{abc}}$ & $0.014^{\mathrm{abcd}}$ & $0.018^{\mathrm{ab}}$ & $0.015^{\text {abcd }}$ \\
\hline & bayad & $0.003^{\text {bcd }}$ & $0.000^{\mathrm{d}}$ & $0.003^{b c d}$ & $0.000^{\mathrm{d}}$ \\
\hline & catfish & $0.026^{\mathrm{a}}$ & $0.019^{\mathrm{ab}}$ & $0.022^{\mathrm{a}}$ & $0.021^{\mathrm{a}}$ \\
\hline \multirow[t]{3}{*}{$\mathrm{Ni}$} & bulti & $0.109^{\mathrm{e}}$ & $0.131^{\mathrm{d}}$ & $0.151^{b c}$ & $0.138^{\mathrm{cd}}$ \\
\hline & bayad & $0.072^{f}$ & $0.030^{\mathrm{g}}$ & $0.071^{\mathrm{f}}$ & $0.004^{\mathrm{h}}$ \\
\hline & catfish & $0.190^{\mathrm{a}}$ & $0.163^{b}$ & $0.188^{\mathrm{a}}$ & $0.185^{\mathrm{a}}$ \\
\hline
\end{tabular}

Means with different superscript letters for each metal are statistically significant at $p \leq 0.05$

The concentration of each of $\mathrm{Fe}, \mathrm{Mn}, \mathrm{Cu}, \mathrm{Cd}$, and $\mathrm{Ni}$ expressed in $\mu \mathrm{g} / \mathrm{g}$ wet wt. in the muscle tissues of each of bulti, $O$. niloticus; bayad, B. bayad; and the catfish, C. gariepinus, were significantly different during all seasons, except that of $\mathrm{Cd}$-ion in the case of $C$. gariepinus (Table 2). It is noticed that, the highest values concentrations of each of $\mathrm{Fe}, \mathrm{Mn}, \mathrm{Cu}, \mathrm{Cd}$, and $\mathrm{Ni}$ were recorded in summer season in both of the fish species bayad, B. bayad; and the catfish, C. gariepinus. However, the highest concentrations of these metals in the muscle tissue of bulti, O. niloticus, were recorded during winter season except that of Fe metal, which recorded in autumn season. On the other hand, the lowest values of the five heavy metals concentrations were, in general, recorded during autumn season with some values which recorded during either spring or summer seasons.

The correlation coefficient and regression analysis between concentrations of heavy metals in muscles of each of the studied fishes; bulti, bayad, and catfish and the concentrations of these heavy metals in water are shown in Table ( 3 ). There are significant positive correlation at $(p \leq 0.05)$ between the concentrations of each of Fe and Mn in water and the muscles of each of bulti and catfish, respectively. On the other hand, there were significant negative 
correlation at $(p \leq 0.05)$ between the concentrations of each of $\mathrm{Cu}$ and $\mathrm{Cd}$ in water and the concentration of these metals in the muscles of each of bulti and catfish.

Table 3:- The correlation coefficient ( $r$ ) and regression analysis between heavy metal concentrations in water and muscles of the tested fishes.

\begin{tabular}{|c|c|c|c|c|}
\hline \multirow{2}{*}{ Metal } & Fish & r & \multicolumn{2}{|c|}{ Regression } \\
\cline { 2 - 5 } & & & $\mathbf{a}$ & B \\
\hline \multirow{3}{*}{ Fe } & bulti & $0.978^{*}$ & 1.54 & 0.30 \\
\cline { 2 - 5 } & bayad & -0.807 & 1.86 & -0.17 \\
\cline { 2 - 5 } & catfish & -0.733 & 4.2 & -0.16 \\
\hline \multirow{3}{*}{$\mathbf{C u}$} & bulti & 0.562 & -0.02 & 0.22 \\
\cline { 2 - 5 } & bayad & 0.730 & 0.003 & 0.127 \\
\cline { 2 - 5 } & catfish & $0.823^{*}$ & 0.15 & -0.051 \\
\hline \multirow{3}{*}{$\mathbf{C d}$} & bulti & $-0.968^{*}$ & 0.028 & -0.054 \\
\cline { 2 - 5 } & bayad & -0.774 & 0.011 & -0.158 \\
\cline { 2 - 5 } & catfish & $-0.843^{*}$ & 0.045 & -0.045 \\
\cline { 2 - 5 } & bulti & -0.34 & 0.19 & -0.043 \\
\cline { 2 - 5 } & bayad & -0.567 & 0.005 & -0.073 \\
\hline \multirow{2}{*}{$\mathbf{N i}$} & catfish & $-0.883^{*}$ & 0.028 & 0.171 \\
\cline { 2 - 5 } & bulti & 0.533 & 0.091 & 0.323 \\
\cline { 2 - 5 } & bayad & 0.707 & -0.033 & 0.121 \\
\cline { 2 - 5 } & catfish & 0.464 & 0.152 & \\
\hline
\end{tabular}

*significant at $p \leq 0.05$

\section{Discussion:-}

The Nile River has been subjected to different sources of pollution and contamination through several and complicated routes. Industrial effluents constitute a real threat to The Nile River. Recently, the risk of water pollution with toxic chemicals not limited to the public health and veterinary public health only but extended and jointed as toxic chemicals causing zoonotic diseases as reported by (El-Tras et al., 2011). The Nile River at Kafr ElZayat, is impacted by several industrial outfalls from oil and soap, fertilizers, pesticides and sulfur industry (El-Malh and Soda, El-Malyia and El-Mobidat factories). There were other sources of pollution and contamination as agricultural drains, laying carcasses and sewage which discharged from several villages distributed along the two banks of the Rosetta Branch. In general, the distribution of these metals at the area under investigations are strongly affected by the industrial effluents produced from El-Mobidat, El-Malyia and Salt and Soda companies which directly discharge industrial effluents at this area without any treatment (Issa et al. 1996).

Different species of fish may be used to determine the mechanisms of action of pollutants on specific physiological functions (Gul et al., 2004). Because fish respond with great sensitivity to changes in aquatic environment, they are one of the most indicative factors in aquatic environment for estimation of trace metals pollution and risk potential of human consumption (Authman et al., 2013). Hence, it is important to determine the concentration of heavy metals in commercial fish in order to evaluate the possible risk of fish consumption (Yilmaz et al., 2007). Bioaccumulation of heavy metals in tissues of aquatic organisms has been identified as an indirect measure of the abundance and availability of metals in the aquatic environment (Kucuksegin et al., 2006). For this reason, monitoring fish tissue contamination represent an important function as an early warning indicator of related water quality problems and enables ou to take appropriate action to protect public health and the environment (Murtala $\boldsymbol{e t}$ al., 2012). Fish accumulate metals may from metal complex with the structural proteins, enzymes and nucleic acids which interrupt their functions and leading to morphological, histological and biochemical alteration in the tissues which may critically influence fish health (Ismail and Saleh, 2012).

Generally metal concentration may differ greatly between one organism and another and between different organs of the same organism (Watanabe et al., 2003; Massoud et al., 2007). The distribution pattern of the heavy metals Fe, $\mathrm{Mn}, \mathrm{Cd}, \mathrm{Cu}$ and $\mathrm{Ni}$, had different concentration in muscles of the three species of fish. According to Sorensen (1991) bioaccumulation of heavy metals depend on the interaction between metals and the target organ. The obtained results of all toxic trace metals in muscles in different species of fish indicate the presence of agricultural 
and domestic wastes as environmental pollutants among the studied sites and their accumulation edible and nonedible fish tissues.

In conclusion, the results demonstrate that the Nile River at Kafr El- Zayat industrial area is heavily polluted and consequently harmful effects to the aquatic environment and to the quality of the water are established. So, pretreatment of different wastes through chemical and microbiological unit before discharging to the River Nile stream is recommended.

\section{References:-}

1. APHA (American Public Health Association) (2005): Standard methods for the examination of water and wastewater. American Water Works Association, New York.

2. Authman MMN, Ibrahim SA, El-Kasheif MA and Gaber HS (2013): Heavy metals pollution and their effects on gills and liver of Nile catfish, Clarias gariepinus inhabiting El-Rahawy drain, Egypt. Global Vet., 10 (2): 103-115.

3. Boyd CE (1990): Water quality in Ponds for Aquaculture. Birmingham Publishing Co. Birmingham, Alabama. U. S. A.

4. Demirezen D and Uruc K (2006): Comparative study of trace elements in certain fish, meat and meat products. Meat Sci., 74(2): 255-260.

5. El-Naggar GO, Zaghloul KH, Salah El-Deen MA and Abo-Hegab S (1998): Studies on the effect of industrial water pollution along different sites of the River Nile on some physiological and biochemical parameters of the Nile tilapia, Oreachromis niloticus. $4^{\text {th }}$ Vet. Med. Zag. Congress (26-28 August 1998, Hurghada), pp. 713-735.

6. El-Tras WF, El-Kady NN and Tayel AA (2011): Infants exposure to aflatoxin M1 as a novel foodborne zoonoses. Food and Chemical Toxicology 49: 2816-2819.

7. Has-Schon E, Bogut I and Strelec I (2006): Heavy metal profile in five fish species included in human diet, domiciled in the endflow of River Neretva (Croatia). Arch. Environ. Contam. Toxicol., 50(4): 545-551.

8. Ismail I and Saleh IM (2012): Analysis of heavy metals in water and fish (Tilapia sp.) samples from Tasik Mutiara, Puchong. Malaysian L. Analytic. Sci., 16(3): 346-352.

9. Issa YM, Elewa AA, Rizk MS and Hassouna A FA (1996): Distribution of some heavy metals in Qaroun Lake and River Nile, Egypt, Menofiya J. Agric. Res., 21(3): 733- 746.

10. Kucuksegin FA, Kontas O, Altay E and Uluturhan DE (2006): Assessment of marine pollution in Izmir Bay: Nutrient, heavy metal and total hydrocarbon concentration. Environ. Int., 32: 41-51.

11. Massoud SAH and Mahadi HA (1985): Liminological investigation of Rosetta branch of the Nile River (Egypt). I. Environmental conditions. Fresh Water Biology, 15(6): 645- 653.

12. Murtala BA, Abdul WO and Akinyemi AA (2012): Bioaccumulation of heavy metal in fish ( Hydrocynus forskahlii, hyperopisus bebe occidentalis and Clarias gariepinus) organs in downstream Ogun coastal water, Nigeria. Trans. J. Sci. Tech., 2(5).

13. Olaifa FE, Olaifa AK, Adelaja A and Owolabi AG (2004): Heavy metal contamination of Clarias gariepinus from a lake and fish from farm in Ibadan, Nigeria. A f. J. of Biomed. Res., 7: 145-148.

14. Sorensen EM (1991): Metal poisoning in fish.Environmental and life Sciences Associates. Austin, Texas. CRC Press Inc., Boston.

15. Watanabe KH, Desimone FW, Thiyagarajah A, Hartley WR and Hindrichs AE (2003): Fish tissue quality in the lower Mississippi River and health risks from fish concumption. Sci. Total Environ., 302: 109-126.

16. Yilmaz F, Ozdemir N, Demirak A and Tuna A (2007): Heavy metal levels in two fish species Leuciscus cephalus and Lepomis gibbosus. Food Chem., 100: 830-835.

17. Zaghloul KH, Abbas HH, Aghouz HM and Mohamed HH (2001): Effect of different levels of dietary vitamin $\mathrm{C}$ on growth indices and some physiological and biochemical responses of the African catfish; Clarias gariepinus. J. Egypt. Ger. Soc. Zool., 35(A): 131-146.

18. http://www.journalijar.com/wp-content/plugins/really-simple-captcha/tmp/1700807026.png. 